ARTICLE

\title{
GP205, a new hepatitis C virus NS3/4A protease inhibitor, displays higher metabolic stability in vitro and drug exposure in vivo
}

\author{
Pei-bin Zhai ${ }^{1,2}$, Jie Qing ${ }^{3}$, Ben $\mathrm{Li}^{2}$, Lin-qi Zhang ${ }^{3}$, Lan Ma ${ }^{1}$ and Li Chen ${ }^{2}$
}

\begin{abstract}
NS3/4A serine protease is a prime target for direct-acting antiviral therapies against hepatitis C virus (HCV) infection. Several NS3/4A inhibitors have been widely used in clinic, while new inhibitors with better characteristics are still urgently needed. GP205 is a new macrocyclic inhibitor of NS3/4A with low nanomolar activities against HCV replicons of genotypes $1 \mathrm{~b}, 2 \mathrm{a}, 4 \mathrm{a}$, and $5 \mathrm{a}$, with $\mathrm{EC}_{50}$ values ranging from 1.5 to $12.8 \mathrm{nmol} / \mathrm{L}$. In resistance selection study in vitro, we found resistance-associated substitutions on D168: The activity of GP205 was significantly attenuated against 1b replicon with D168V or D168A mutation, similar as simeprevir. No cross resistance of GP205 with NS5B or NS5A inhibitor was observed. Combination of GP205 with sofosbuvir or daclatasvir displayed additive or synergistic efficacy. The pharmacokinetic profile of GP205 was characterized in rats and dogs after oral administration, which revealed good drug exposure both in plasma and in liver and long plasma half-life. The in vitro stability test showed ideal microsomal and hepatic cells stability of GP205. The preclinical profiles of GP205 support further research on this NS3/ $4 \mathrm{~A}$ inhibitor to expand the existing HCV infection therapies.
\end{abstract}

Keywords: HCV; NS3/4A; direct acting antiviral therapy; GP205; sofosbuvir; daclatasvir

Acta Pharmacologica Sinica (2018) 39:1746-1752; https://doi.org/10.1038/s41401-018-0046-2

\section{INTRODUCTION}

Chronic infection with hepatitis $\mathrm{C}$ virus (HCV) has been reported to affect 170 million people worldwide. Approximately 700,000 people die each year from HCV-related complications [1-3]. HCV is a leading cause of liver fibrosis and cirrhosis that may eventually lead to hepatocellular carcinoma [1].

The existing standard of care (SOC) based on parenteral administration of pegylated interferon-a (PEG-IFN- $a$ ) together with ribavirin (RBV) has a number of deficiencies [4]. Direct-acting antivirals (DAAs) - agents targeting non-structural HCV proteinsincluding NS3/4A, NS5A, and NS5B, have been widely used clinically, and a higher sustained virus response (SVR) rate with fewer side effects has been achieved in treating chronic HCVinfected patients. NS3/4A-NS5B [5], NS3/4A-NS5A [6, 7], NS5ANS5B $[8,9]$, and NS3/4A-NS5A-NS5B [10] inhibitor combinative therapies are now available to treat genotype 1 and other genotypes in chronic HCV infection [3].

The NS3/4A protein has serine protease activity and is an essential non-structural protein required for viral replication [11], and the NS3/4A protein may protect the virus from host immune responses [12]. It has been well demonstrated that NS3/4A protease inhibitors (PIs) can effectively prevent virus proliferation both in vitro and in vivo. Two Pls, boceprevir and telaprevir, have been validated for treating chronic HCV infection in combination with PEG-IFN-a plus RBV $[13,14]$. Currently, PIs have been found to be essential in DAA combination therapies $[5,7]$. However, the negative characteristics of available Pls, such as their relatively low activities, ineffectiveness with non-genotype 1 viruses, fast plasma clearance, and so on, have limited their use. Novel Pls with better characteristics still need to be explored to improve DAAs combination therapies.

The original PIs were designed based on the peptide-like substrates of the NS3/4A protease. Intramolecular cyclization of the original PI structures was thought to be useful in improving the stability of the compounds while maintaining their activity [15]. In previous works, we found a new series of Pls with 18membered-macrocycle structures, from which GP205 was chosen as a lead because of its better antivirus activity and good stability in in vitro tests. Here, we describe the key preclinical findings of the new macrocycle HCV NS3/4A inhibitor GP205 (Fig. 1a).

\section{MATERIALS AND METHODS}

Compounds and reagents

GP205, sofosbuvir, daclatasvir, and telaprevir were synthesized by GinkgoPharma, China. KK4A peptides ( $\mathrm{NH}_{2}-\mathrm{KKGSVVIVGRIVLSGK-}$ $\mathrm{COOH}$ ) were synthesized by GL Biochem (Shanghai) Ltd, China. The MEGAscript T7 High-Yield Transcription Kit was obtained from Ambion (Carlsbad, CA, USA). The HCV protease FRET substrate (RET S1) (sequence: Ac-Asp-Glu-Asp(EDANS)-Glu-GluAbu- $\Psi$-[COO]-Ala-Ser-Lys(DABCYL)- $\mathrm{NH}_{2}$ ) was obtained from AnaSpec, Inc (Fremont, CA, USA). The Renilla-Glo ${ }^{\mathrm{TM}}$ Luciferase Assay

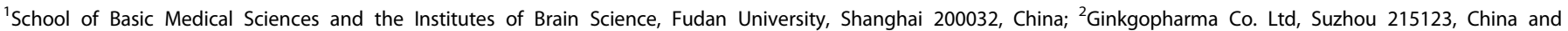
${ }^{3}$ Comprehensive AIDS Research Center and Research Center for Public Health, School of Medicine, Tsinghua University, Beijing 100084, China

Correspondence: Pei-bin Zhai (12111010100@fudan.edu.cn) or Li Chen (chenli@ginkgopharma.com)
} 
a

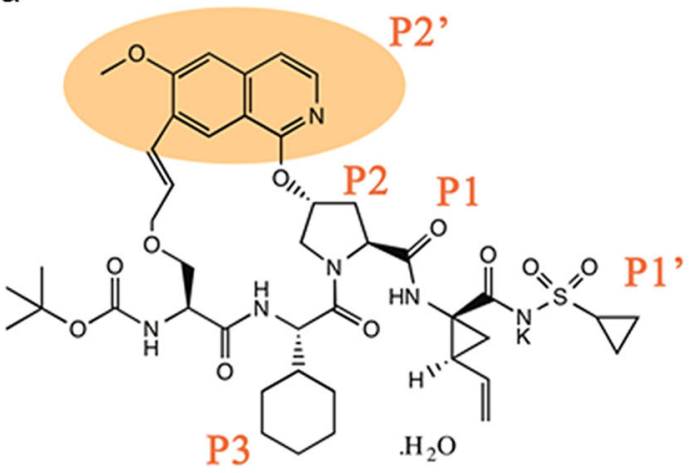

b

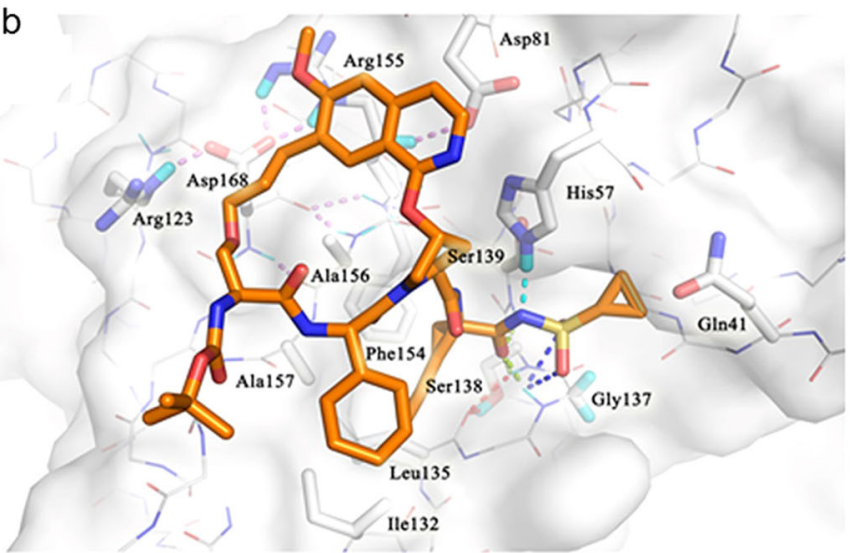

Fig. 1 Interaction of the HCV NS3 protein with GP205. a Chemical structure of GP205. P and $\mathrm{P}^{\prime}$ labeling indicates the GP205 moieties that correspond to the natural HCV substrate positions occupying the NS3 protease active site. $\mathbf{b}$ Crystal structure of GP205 bound to WT NS3/4A

System kit was obtained from Promega (Madison, WI, USA). The cell viability and proliferation assay kit (WST-1) was obtained from Roche Applied Science (Mannheim, Germany). Human plasmin, kallikrein, and alpha-thrombin were obtained from Calbiochem (La Jolla, CA, USA). Human factor Xa was obtained from Abcam (Cambridge, MA, USA). The protease substrates $\mathrm{H}$-[d-lle]-Phe-Lys-pNA， H-[d-Val]-Leu-Arg-pNA, Boc-lle-Glu-GlyArg-AMC, and Bz-Phe-Val-Arg-pNA and protease inhibitors $\mathrm{H}$-[dPhe]-Pro-Arg-chloromethyl ketone and D-VLK-CMK were obtained from Bachem (King of Prussia, PA, USA). Leupeptin was obtained from Bachem (King of Prussia, PA, USA). The plasmids $p E T 22 b$, pET28a, pMD18, and pFKI were obtained from Novagen, Darmstadt, Germany. Liver mircosomes of rats, dogs, and humans; Liver Pool suspended human primary hepatic cells; and testosterone were obtained from the Research Institute for Liver Diseases (Shanghai) Co., Ltd. China.

Replicon and cell lines

The genotype $1 \mathrm{~b}$ (con 1 ) and $2 \mathrm{a}(\mathrm{JFH}-1)$ replicons including a Rluc reporter and the Huh7 and Huh7.5.1 cell lines were obtained from Apath, L.L.C (New York, NY, USA). The 1b/3a, 1b/4a, 1b/5a chimera replicons with Rluc reporters were obtained from Wuxi AppTec (Shanghai China). PR63 replicon testing was performed by the lab of Prof. Jin Zhong (Institut Pasteur of Shanghai, China) [16]. The JFH-1 virus with an EGFP reporter gene (J399EM) was a gift from Xinwen Chen (Wuhan Institute of Virology, Chinese Academy of Science) and is an infectious HCV monocistronic reporter virus that was constructed by inserting an EGFP reporter gene into the Cterminus between amino acids 399 and 400 of NS5A in the JFH-1 genome.

HCV NS3 protein and biochemical protease assay

Recombinant HCV NS3 (residues 1-181) protease was expressed and purified from Escherichia coli. The NS3 protease, derived from pFKI-CON1-luc by PCR, was cloned into the pET22b expression vector with a HIS tag fused at the $\mathrm{N}$-terminus according to a general protocol. Inhibition of the HCV NS3 protease activity in reactions containing GP205 or the reference compound telaprevir was determined in a time-resolved fluorescence assay with a 20 $\mathrm{nM}$ concentration of the NS3 protease in the system as described previously [17].

Cell culture virology assays

Cells were seeded at a density of $2 \times 10^{4}$ cells/well in a 96-well plate in Dulbecco's modified Eagle's medium (DMEM) plus $10 \%$ fetal calf serum or 20 or $40 \%$ human fetal serum. Replicons were transfected into Huh7.5.1 cells as reported previously [18]. Cell incubation, drug treatments, luciferase signal measurements, and RNA detection were conducted as before [19]. The viability of Huh7.5.1 cells was determined using the cell proliferation reagent WST-1 (Roche), and the absorbance (OD450/reference OD630) was measured to detect the cytotoxicity of the compounds according to the manufacturer's protocol for Cell Proliferation Reagent WST1 with a Model680 Microplate reader (BIO-RAD, Hercules, CA, USA).

\section{Combination studies}

GP205, in combination with sofosbuvir or daclatasvir, was added at various concentrations $(0-30 \mathrm{nM}$ for GP205, 0-1.6 $\mu \mathrm{M}$ for sofosbuvir, $0-0.120 \mathrm{nM}$ for Daclatasvir) to DMEM containing $10 \%$ FBS in a 96-well plate. The inhibition rates of the $1 \mathrm{~b}$ replicon were determined as mentioned above, and the data were analyzed according to the Bliss independence model [20].

Resistance selection assay

For in vitro resistance selections, Huh7.5.1 cells were plated at a density of $3 \times 10^{5}$ cells/well in six-well plates. After culturing at $37^{\circ}$ C with $5 \% \mathrm{CO}_{2}$ in DMEM containing $10 \%$ FBS for $24 \mathrm{~h}$, a 0.5 multiplicity of infection (moi) amount of the J399EM virus in the presence of $0.5 \mu \mathrm{M} \mathrm{GP205}$ was added to the medium and incubated for $24 \mathrm{~h}$. Then, the medium was removed and replaced with DMEM containing $0.5 \mu \mathrm{M}$ GP205. After incubation for $\sim 72 \mathrm{~h}$, the medium was replaced with DMEM without GP205. J399EMR viruses were collected from the cell supernatants by centrifugation at $4000 \times g$ for $5 \mathrm{~min}$ and stored at $-80^{\circ} \mathrm{C} 48 \mathrm{~h}$ later. The protocol was repeated three times in the presence of $0.5 \mu \mathrm{M}$ GP205 and two times in the presence of $4.0 \mu \mathrm{M}$ GP205. Newly collected virus from each cycle was used to infect Huh7.5.1 cells in the next cycle.

For RNA-resistant mutation analysis, cellular RNA extraction was performed with TRIzol reagent (Invitrogen, Carlsbad, CA, USA) following the manufacturer's instructions. For reverse transcription $P C R$, the first strand of CDNA was synthesized using random primers and the Super Script III First-strand Synthesis System for RT-PCR (Invitrogen, Carlsbad, CA, USA). The HCV protein-coding region JFH-1 NS3 was amplified by PCR using the following sequences: NS3sense: 5'-CCCGAATTCCAGCTGATGGCTACACCTCC-3', NS3-anti-sense: 5'-AGTCCTAATGTTGGGATTG-3'. The RT-PCR product of the resistant J399EMR1 virus or control JFH-1 virus was ligated into the TA cloning vector PMD18. Multiple individual bacterial colonies were isolated, and the purified plasmid DNA was sequenced. The sequences were aligned using Sequencher 5.0 and BioEdit software (Carlsbad, CA, USA). 
Cross-resistance study

The 1b replicon plasmids with NS3-D168V, NS3-D168A, NS3-Q80K, NS5A-Y93H, NS5A-L31V, and NS5B-S282T mutations were introduced using a QuikChange Lightning Site-Directed Mutagenesis Kit (Agilent Technologies, Santa Clara, CA, USA), following the manufacturer's instructions. Mutations were confirmed by DNA sequencing.

Pharmacokinetic studies

Male SD rats and beagles were fed a certified standard diet and water ad libitum. The temperature and humidity were regulated at $21-23^{\circ} \mathrm{C}$ and $30-60 \%$, respectively. Animal procedures were performed according to the institutional ethical guidelines for animal care. For oral studies, the crystalline potassium salt of the compound was dosed as a solution in a mixed solvent (5\% DMSO, $40 \%$ PEG-400, 55\% physiological saline). For all studies, blood samples were collected in EDTA-containing tubes at appropriate times, and the plasma samples were separated by centrifugation ( $3500 \mathrm{r} / \mathrm{min}$ for $10 \mathrm{~min}$ ) and stored at $-80^{\circ} \mathrm{C}$ until analysis. Tissue samples were obtained at the pre-determined time points, rinsed, blotted dry, weighed and stored at $-80^{\circ} \mathrm{C}$ until analysis. After protein precipitation, the GP205 concentration was quantified by high-performance liquid chromatography/mass spectroscopy on a Varian HPLC-MS/MS system (Palo Alto, CA, USA) [21].

\section{Equilibrium dialysis assay}

Tests were performed with fresh rat, dog, and human serum, with final concentrations of GP205 at 10, 200, and $4000 \mathrm{ng} / \mathrm{mL}$. The materials and protocol used were based on a previously described method [22]. Samples were analyzed by LC-MS/MS, and the percentage of protein binding was calculated as the protein concentration in potassium phosphate buffer $(\mathrm{pH}$ 7.4) relative to that in serum.

In vitro stability test

First, 0.5 or $5.0 \mu \mathrm{M} \mathrm{GP} 205$ was incubated at $37^{\circ} \mathrm{C}$ with $1.0 \mathrm{mg} / \mathrm{mL}$ microsomes from rats, dogs, or humans in the presence of $1.0 \mathrm{mM}$ $\beta$-NADPH for up to $120 \mathrm{~min}$. The reaction was terminated with icecold acetonitrile containing $3 \%$ formic acid. The concentration of GP205 left at the determined time was measured by LC/MS/MS. As a control, $0.5 \mu \mathrm{M}$ testosterone was tested in parallel.

Table 1. Enzyme kinetics parameters of the $1 \mathrm{~b}-\mathrm{NS} 3$ protein and the $\mathrm{IC}_{50}$ of GP205 against the NS3 protease

\begin{tabular}{llcr}
\hline & \multicolumn{2}{l}{ Enzyme kinetics parameters } & Inhibiting \\
\cline { 2 - 4 } & $V_{\text {max }}(\mathrm{V} / \mathrm{min})^{\mathrm{a}}$ & $K_{\mathrm{m}}{ }^{\mathrm{a}}$ & $\mathrm{IC}_{50}(\mathrm{nM})^{\mathrm{a}}$ \\
\hline $\begin{array}{l}\text { GP205 } \\
\text { Telaprevir }\end{array}$ & 5.1 & $0.40 \pm 0.15$ \\
\hline $\begin{array}{l}\text { aValues are reported as mean standard deviation based on a minimum of } \\
\text { three independent experiments } \\
\text { bTelaprevir was the most suitable control at the time this test was done. It } \\
\text { was replaced once after another Pl: simeprevir was available }\end{array}$ \\
\hline
\end{tabular}

Selectivity assays

Protease selectivity assays with human kallikrein, thrombin, plasmin, and factor Xa were performed following a previously described method [13].

\section{RESULTS}

Detailed structural analysis of GP205 binding to NS3/4A

GP205 is a second-generation PI that was found based on structural optimization and in vitro screening; GP205 was characterized by a macrocycle consisting of $\mathrm{P} 2, \mathrm{P} 2$ ', and $\mathrm{P} 3$ moieties (Fig. 1a). The pattern of GP205 binding to NS3/4A is shown in Fig. $1 \mathrm{~b}$. The proline-like P2 moiety docks into the S2 pocket and the hydrophobic alkyl of $\mathrm{P} 3$, which together with the alkenyl of $\mathrm{P} 1-\mathrm{P} 1^{\prime}$, dock into the S3 pocket. The methoxy isoquinoline moiety of $\mathrm{P} 2$ ' interacts with Arg155 and Ala156 and affects the electrostatic network composed of Asp81, Arg123, Arg155, Ala156, and Asp168. Based on the structural analysis results, GP205 was speculated to be a PI inhibitor with a similar activity and resistance profile to those of MK-5172 [23].

Biochemical activities and selectivity

The NS3/4A protein of genotype $1 \mathrm{~b}$ (con 1) was purified and tested in a peptide cleavage assay. The main enzyme kinetics parameters were obtained as $V_{\max }=8.7 \mathrm{~V} / \mathrm{min}$ and $K_{\mathrm{m}}=5.1$. GP205 inhibits the NS3/4A protease with sub-nanomolar potency $\left(I C_{50}=0.40 \mathrm{nM}\right)$, which is much more potent than telaprevir $\left(I C_{50}=93.0 \mathrm{nM}\right)$ (Table 1). Then, we explored its selectivity by testing human serine protease. No inhibiting activities were observed against a panel of representative human serine proteases, including kallikrein, thrombin, plasmin, and factor $\mathrm{Xa}$, with GP205 concentrations up to $10 \mu \mathrm{M}$ (data not shown). These results indicated that GP205 can efficiently and selectively inhibit the HCV NS3/4A protease in vitro.

In vitro replicon activities

In cell-based assays, GP205 demonstrated high potency against the genotype $1 \mathrm{~b}$ (con 1 ) and $2 \mathrm{a}(\mathrm{JFH}-1)$ replicons $\left(\mathrm{EC}_{50}=1.5\right.$ and $9.0 \mathrm{nM}$, respectively). In a genotype $2 \mathrm{a}$ replicon named PR63 derived from a Chinese patient [16], GP205 showed a higher potency than simeprevir ( $\mathrm{EC}_{50}=11.3 \mathrm{nM}$ versus $115.2 \mathrm{nM}$ ). GP205 also demonstrated high activity against genotype $4 a$ and $5 a$ chimera replicons, with $\mathrm{EC}_{50}$ values of 3.5 and $12.8 \mathrm{nM}$, respectively. Reduced potency was observed against the genotype 3a chimera replicon for both GP205 and simeprevir in our tests (EC $50>200 \mathrm{nM}$ for both). The antiviral activity of GP205 was attenuated by approximately 3- or 4-fold in the presence of 20 or $40 \%$ human serum compared to that with $10 \%$ fetal bovine serum when tested with the $1 \mathrm{~b}$ replicon (Table 2). Low cellular cytotoxicity was found in all cell culture assays with GP205 $\left(\mathrm{CC}_{50}>100 \mathrm{nM}\right)$.

Resistant selection and cross-resistance

Resistance selection studies were performed using J399EM, a genotype-2a virus containing an EGFP reporter gene. To maintain

Table 2. Antiviral activity of GP205 against HCV replicons

\begin{tabular}{|c|c|c|c|c|c|c|c|c|c|}
\hline & $\begin{array}{l}1 b^{a} \\
\text { Con1 }\end{array}$ & \multicolumn{2}{|l|}{$2 a^{a}$} & $\begin{array}{l}\text { 1b/3a NS3 }{ }^{a} \\
\text { Con1 chimera }\end{array}$ & $\begin{array}{l}\text { 1b/4a NS3 }{ }^{a} \\
\text { Con1 chimera }\end{array}$ & $\begin{array}{l}\text { 1b/5a NS3 }{ }^{\mathrm{a}} \\
\text { Con1 chimera }\end{array}$ & \multicolumn{3}{|l|}{$1 b$} \\
\hline Simeprevir & $0.9 \pm 0.1$ & $11.6 \pm 4.5$ & $115.2 \pm 20.4$ & $>200$ & $0.5 \pm 0.3$ & $52.1 \pm 10.2$ & - & - & - \\
\hline
\end{tabular}




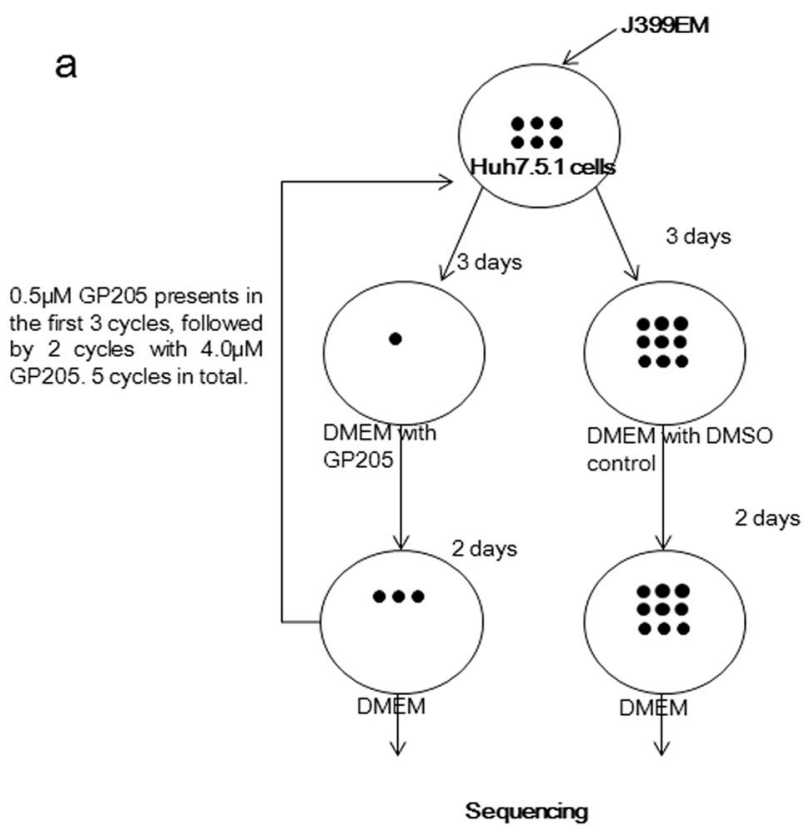

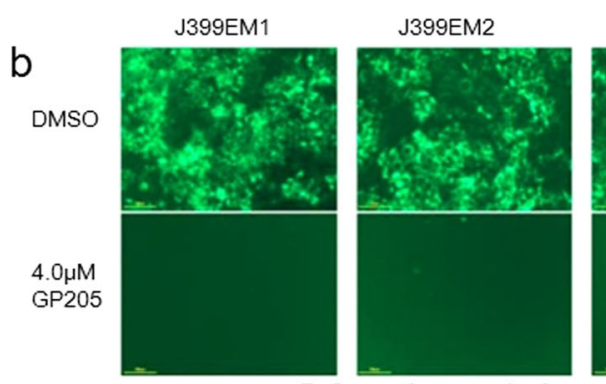

Before resistanoeselection

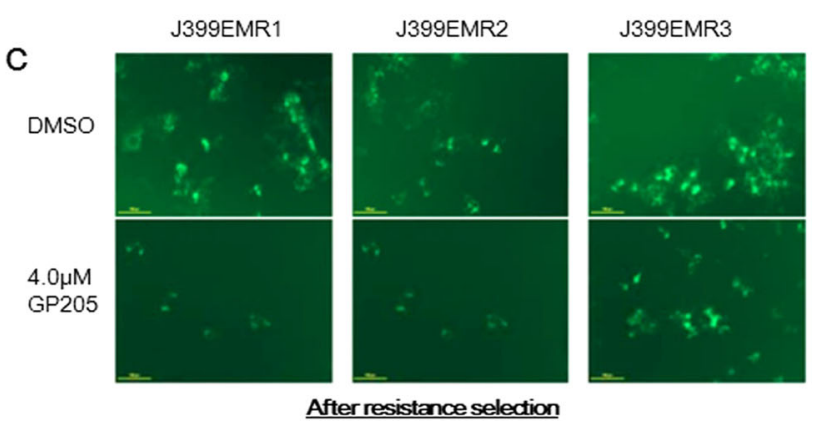

Fig. 2 Drug resistance selection. a Huh7.5.1 cells with hepatitis C virus J399EM were incubated with $0.5 \mu$ M GP205 for three selection cycles, followed by $4.0 \mu \mathrm{M}$ GP205 for two cycles. Resistance clones in plates were chosen for RNA sequencing. b EGFP-positive cells before resistance selection. A low EGFP signal was found in cultures before selection when treated with $4.0 \mu \mathrm{M}$ GP205. c EGFP-positive cells after three cycles of selection

Table 3. In vitro activities of GP205 against NS3/4A-, NS5B-, and NS5Aresistant genotypes $\left(\mathrm{EC}_{50} \mathrm{nM}, 1 \mathrm{~b}\right.$ replicon)

\begin{tabular}{|c|c|c|c|c|c|c|}
\hline \multirow[b]{2}{*}{ Mutants } & \multicolumn{3}{|c|}{ NS3 variants ${ }^{a}$} & \multicolumn{2}{|c|}{$\begin{array}{l}\text { NS5A } \\
\text { variants }^{\text {a }}\end{array}$} & \multirow{2}{*}{$\begin{array}{l}\text { NS5B variants }{ }^{a} \\
\text { S282T }\end{array}$} \\
\hline & Q80K & D168V & D168A & Y93H & L31V & \\
\hline GP205 & 3.3 & 442.4 & 227.4 & 0.2 & 0.6 & 1.0 \\
\hline Simeprevir & 8.2 & 521.1 & 643.3 & - & - & - \\
\hline Daclatasvir & - & - & - & 20.7 & 14.3 & - \\
\hline Sofosbuvir & - & - & - & - & - & 1060 \\
\hline
\end{tabular}

J399EM proliferation when treated with GP205, Huh7.5.1 cells were infected by the virus in the presence of gradually increasing concentrations of the compound along with supernatantcollected reinfection (Fig. 2a). In the first three incubation cycles, medium containing $0.5 \mu \mathrm{M}$ GP205 was used, followed by two cycles with medium containing 4.0 $\mu \mathrm{M}$ GP205. Low EGFP signal was found in cultures before selection when treated with $4.0 \mu \mathrm{M}$ GP205 (Fig. 2b). After the first three selection cycles, we observed a difference in the fluorescent foci only between the plates treated with or without $4.0 \mu \mathrm{M} \mathrm{GP205}$ (Fig. 2c). Three strains of the resistant virus, J399EMR1, J399EMR2, and J399EMR3, were collected. In total, 21 clones were chosen from the resistant strains for NS3 1-185aa sequencing. All but one resistanceassociated substitution (RAS) site was identified on D168 (10 clones for D168V and 1 for D168A). Several other single-base mutations were proven to be eventually transformed back to that of the wild-type virus (data not shown). In reconstructed $1 \mathrm{~b}$ replicons with the D168V or D168A mutation, GP205 demonstrated a more than 100 -fold shift of the $\mathrm{EC}_{50}$, as did simeprevir. A minor shift against Q80K was observed in our tests. No cross- resistances were observed for GP205 against the NS5A resistanceassociated variants (RAVs) $\mathrm{Y} 93 \mathrm{H}$ and L31V [24] and NS5B RAV S282T [25] (Table 3).

Combination study of GP205 with sofosbuvir or daclatasvir To examine the combined activities of GP205 with other DAAs, we chose sofosbuvir and daclatasvir for a combination study with the $1 \mathrm{~b}$ con 1 replicon. The results revealed concentration-dependent inhibition of HCV replication by GP205, sofosbuvir or daclatasvir alone or by any two of them in combination. Using a Bliss independence model to analyze the tests with varied drug ratios, the effect of GP205 was found to be additive when combined with sofosbuvir (Fig. 3a) and to be additive or synergistic when combined with daclatasvir (Fig. 3b). The synergy effect was most significant at a lower concentration of GP205 (1.9 nM) with a moderate concentration of daclatasvir $(0.015 \mathrm{nM})$, with the maximal synergy range about $14.95 \%$ (Fig. 3c). These results indicated that GP205 can combine with either the NS5B or NS5A inhibitors to achieve higher antiviral activities.

\section{Pharmacokinetics}

The pharmacokinetic profile of GP205 was measured in rats and dogs (Table 4). Referring to the study of simeprevir [19], an oral dose of $40 \mathrm{mg} / \mathrm{kg}$ was selected first for rats in a PK study. However, in the pre-test, we found an extremely high $C_{\max }$ and AUC for GP205. The dose was reduced to $5 \mathrm{mg} / \mathrm{kg}$ for GP205, while $40 \mathrm{mg} /$ $\mathrm{kg}$ was still used for simeprevir. Based on the body surface area dose conversion, $1.5 \mathrm{mg} / \mathrm{kg}$ was determined to be the oral dose for dogs.

In the PK study in rats, an oral $5 \mathrm{mg} / \mathrm{kg}$ dose of GP205 demonstrated significantly higher plasma exposure $\left(A \cup C_{0-t}\right.$ as $163723.2 \mathrm{nM} . \mathrm{h})$ and longer half-life $(9.2 \mathrm{~h})$ than an 8-fold higher dose of simeprevir $(40 \mathrm{mg} / \mathrm{kg})$. After $24 \mathrm{~h}$ of oral dosing, the liver concentration of GP205 was $390.3 \mathrm{nmol} / \mathrm{g}$, which was approximately 260 -fold greater than the $\mathrm{EC}_{50}$ value of GP205 against the wild-type (WT) 1b replicon. GP205 demonstrated quite exposure with an oral dose of $1.5 \mathrm{mg} / \mathrm{kg}$ in dogs, with a plasma half-life as 


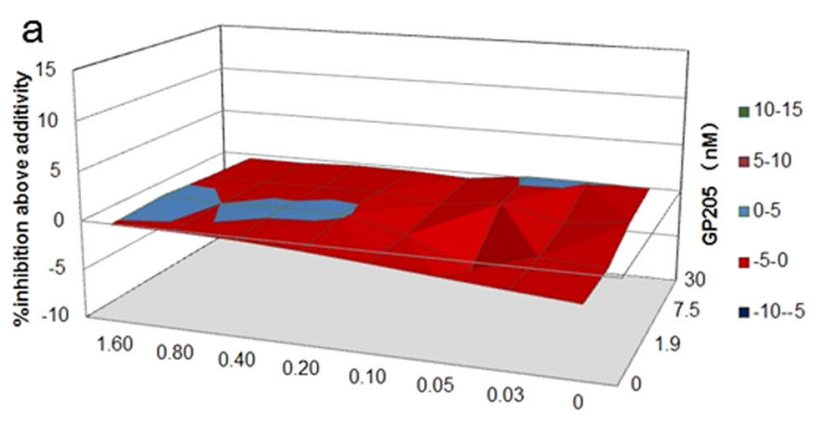

Sofosbuvir ( $\mu \mathrm{M})$

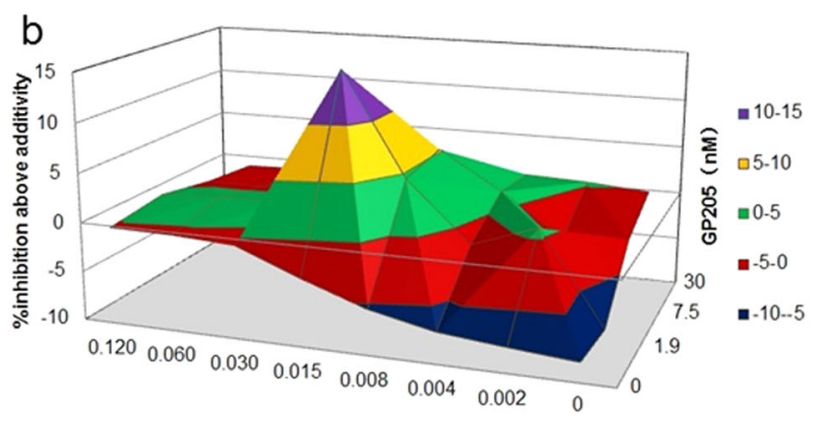

Daclatasvir (nM)

C

\begin{tabular}{ccccc}
\hline \multicolumn{2}{c}{ Combination } & Maximal synergy & Maximal antagonism & Assessment \\
Drug 1 & Drug 2 & range (\%) & range (\%) & \\
\hline GP205 & Sofosbuvir & 0.26 & -4.32 & Additive \\
GP205 & Daclatasvir & 14.95 & -8.57 & Synergistic/additive \\
\hline
\end{tabular}

Fig. 3 Replicon synergy studies of GP205 in combination with sofosbuvir and daclatasvir. Figures are three-dimensional representations of the combined antiviral effects of GP205 with sofosbuvir (a) and of GP205 with daclatasvir (b) determined by Bliss independence modeling of varied drug ratio combinations. A surface higher than 10 indicates synergistic effects, and a surface lower than -10 indicates antagonism. A value in the range from -10 to 10 indicates additive effects. Antiviral combination assays were performed in GT1b (Con 1) replicon cells. Values represent the means of two independent experiments. c The maximal synergy range and maximal antagonism range of GP205 in combination with sofobuvir or with daclatasvir

Table 4. Pharmacokinetic parameters of GP205 in dogs and rats (mean \pm SD)

\begin{tabular}{|c|c|c|c|c|c|c|c|c|}
\hline & Species & $\begin{array}{l}\text { PO dose }{ }^{a} \\
\mathrm{mg} / \mathrm{kg}\end{array}$ & $\begin{array}{l}T_{\max } \\
\mathrm{h}\end{array}$ & $\begin{array}{l}C_{\max } \\
\mathrm{nM}\end{array}$ & $\begin{array}{l}T_{1 / 2} \\
\mathrm{~h}\end{array}$ & $\begin{array}{l}A \cup C_{0-t} \\
n M . h\end{array}$ & $\begin{array}{l}A \cup C_{0-i n f} \\
\text { nM.h }\end{array}$ & $\begin{array}{l}\text { Liver Conc } \\
\mathrm{nmol} / \mathrm{g}\end{array}$ \\
\hline \multirow[t]{2}{*}{ GP205 } & $\operatorname{Dog}^{b}$ & 3 & $3.0 \pm 0.6$ & $345.8 \pm 81.5$ & $7.6 \pm 1.7$ & $1860.8 \pm 366.2$ & $2044.0 \pm 376.5$ & $3680.2 \pm 1250.0$ at $6 h$ \\
\hline & $\operatorname{Rat}^{\mathrm{b}}$ & 5 & $4.0 \pm 1.2$ & $17,837.3 \pm 5077.3$ & $9.2 \pm 1.7$ & $163,723.2 \pm 17,521.0$ & $176,706.0 \pm 21,951.1$ & $390.3 \pm 90.1$ at $24 \mathrm{~h}$ \\
\hline Simeprevir & Rat $^{\mathrm{b}}$ & 40 & $4.0 \pm 0.6$ & $551.3 \pm 109.0$ & $1.8 \pm 0.5$ & $3167.9 \pm 1294.9$ & $3268.8 \pm 1386.2$ & $268.2 \pm 133.3$ at $24 \mathrm{~h}$ \\
\hline
\end{tabular}

${ }^{\mathrm{a} A l l}$ PO formulations are $40 \%$ PEG $400+5 \% \mathrm{DMSO}+55 \%$ Saline

${ }^{\mathrm{b}}$ Three animals at least for each plasma or liver time point data

Table 5. GP205 biodistribution in male rats $6 \mathrm{~h}$ after a $5 \mathrm{mg} / \mathrm{kg}$ oral dose (mean $\pm \mathrm{SD}^{\mathrm{a}}$ )

\begin{tabular}{|lllllll}
\hline Tissues $^{\mathrm{b}}$ & Liver & Heart & Lung & Kidney & Stomach & Small intestine \\
\hline Concentration $(\mathrm{ng} / \mathrm{g})$ & $1075.6 \pm 301.4$ & $227.8 \pm 56.9$ & $219.2 \pm 44.4$ & $228.8 \pm 52.3$ & $279.0 \pm 83.8$ & $218.1 \pm 29.8$ \\
\hline $\begin{array}{l}\text { a Three animals at least for each data } \\
\text { bOther tested tissues with drug concentration below } 200 \mathrm{ng} / \mathrm{g}\end{array}$ & were not show in this table & & & \\
\hline
\end{tabular}

long as $7.6 \mathrm{~h}$. After $6 \mathrm{~h}$ of oral dosing, the liver concentration was $\sim 3680.2 \mathrm{nmol} / \mathrm{g}$, which made the liver/plasma ratio $\sim 66$.

The liver preference of GP205 was confirmed in a rat biodistribution test. The liver concentration of GP205 was $1075.6 \mathrm{ng} / \mathrm{g}$ at $6 \mathrm{~h}$ after the dose, which was significantly higher than that in all other tissues tested in parallel (Table 5).

A relatively moderate plasma protein binding rate (ranging from 69.0 to 87.0\%) was observed for GP205 when tested with rat, dog, or human plasma proteins at drug concentrations ranging from $10 \mathrm{ng} / \mathrm{mL}$ to $4000 \mathrm{ng} / \mathrm{mL}$ using an equilibrium dialysis assay (Table 6).

In the in vitro stability study, a small percent $(<5 \%)$ of GP205 was digested when incubated with human, rat, and dog microsomes or with human primary hepatic cells for as long as $120 \mathrm{~min}$ (Fig. 4). These results were consistent with the high
Table 6. Mean plasma protein binding rate of GP205 after $72 \mathrm{~h}$ of equilibrium dialysis

\begin{tabular}{llll}
\hline & \multicolumn{3}{l}{ Species } \\
\cline { 2 - 4 } Concentration of GP205 $(\mathrm{ng} / \mathrm{mL})$ & Rat $^{\mathrm{a}}$ & Dog $^{\mathrm{a}}$ & Human $^{\mathrm{a}}$ \\
\hline $10 \mathrm{ng} / \mathrm{mL}$ & $84.9 \%$ & $82.2 \%$ & $87.0 \%$ \\
$200 \mathrm{ng} / \mathrm{mL}$ & $80.6 \%$ & $83.2 \%$ & $69.0 \%$ \\
$4000 \mathrm{ng} / \mathrm{mL}$ & $77.1 \%$ & $75.2 \%$ & $84.5 \%$ \\
\hline
\end{tabular}

${ }^{a}$ Values represent the means of at least two independent experiments 


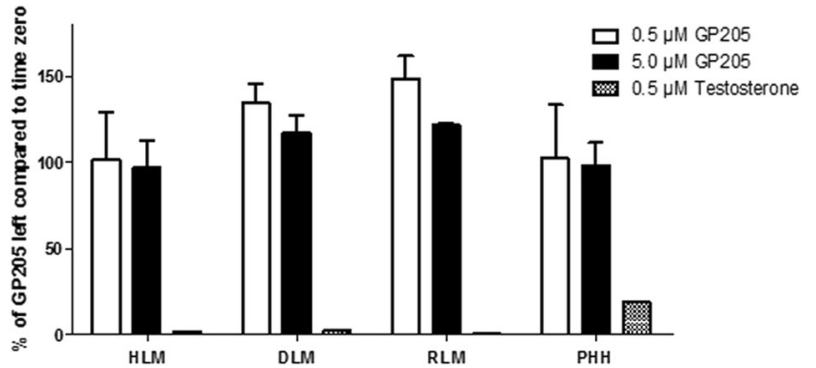

Fig. 4 In vitro stability of GP205. GP205 at a 0.5 or $5.0 \mu \mathrm{M}$ concentration was incubated with human liver microsome (HLM), dog liver microsome (DLM), rat liver microsome (RLM), or Liver Pool human primary hepatocellular suspension (HPH) for up to $120 \mathrm{~min}$. Relative concentrations are compared to that of time zero. As the control, $0.5 \mu \mathrm{M}$ testosterone was chosen

plasma exposure and lower clearance rate we found in the animal PK studies.

\section{DISCUSSION}

NS3/4A is a prime drug target for HCV DAAs combination therapies. There have been at least $6 \mathrm{PIs}$, including telaprevir, boceprevir, simeprevir, asunaprevir, paritaprevir, and grazoprevir, approved for clinical use to treat HCV-infected patients [3], and more are still under investigation [26]. The potency of PIs has been verified in tens of trials, either in combination with IFNs or with other DAAs $[26,27]$. However, their narrow genotype coverage (usually effective only for genotype 1), usually poor plasma exposure, and drug-induced liver injury risk at higher $C_{\max }$ values have limited their use [28-31]. Some PIs-paritaprevir and danoprevir, for example-should be boosted with ritonavir, a CYP enzyme inhibitor, to maintain continuous plasma exposure and a relatively lower $C_{\max }$ when treating patients. Drug-drug interactions should be considered in these cases.

GP205 is a potent PI with extremely high plasma exposure and a longer $t_{1 / 2}$ in both rats and dogs. The observed $A U C$ and $C_{\max }$ of GP205 in rats were 30-fold and 50-fold greater than those of simeprevir, respectively, when orally dosed at $5 \mathrm{mg} / \mathrm{kg}$ of GP205 or $40 \mathrm{mg} / \mathrm{kg}$ of simeprevir in parallel in our study. The observed liverto-plasma ratio in dogs was $\sim 66$, and the concentration of GP205 in the liver was approximately 2400-fold that of the WT 1b replicon $\mathrm{EC}_{50}$ value at $6 \mathrm{~h}$ after administration of a $1.5 \mathrm{mg} / \mathrm{kg}$ oral dose in dogs. These results are consistent with the ideal stability of GP205 in both microsomes and hepatic cell cultures that we found. It appears that CYP enzymes are not the main metabolizing pathway of GP205. Further studies should be performed to probe which metabolic route is responsible. The continuous dose drug accumulation is not a cause for worry in spite of the high exposure and slower clearance in plasma we observed. In 28-day repeateddose toxicity studies, no obvious drug accumulations were observed in both rats and dogs, and most animals were well tolerant to high drug exposure (Table S1, S2). A possible explanation for this result is that the metabolic pathway of GP205 might be activated by repeat doses. Considering all of the results together, it is expected that GP205 can efficiently block $\mathrm{HCV}$ proliferation in patients with a lower oral dose and frequency and does not require boosting by ritonavir.

The moderate plasma protein-binding rate may assist GP205 to achieve better efficacy compared with the plasma exposure of most other Pls. The protein-binding rates of PIs are usually extremely high. The rates of simeprevir and asunaprevir, for example, can reach as high as $\sim 98.0-100 \%[22,32,33]$. A rate of $80 \%$ (the average bind rate of GP205 to human plasma protein) versus $98 \%$ means the free amount of GP205 in plasma is 10 -fold greater than that of simeprevir and asunaprevir at the same plasma concentration. More free compound may also assist in the drug distribution in the liver, which might be beneficial to both the efficacy and safety of GP205 in clinical use. One hypothesis is that there is a dynamic-equilibrium drug distribution between the blood and liver when no transporter contributions are present. More free GP205 in the blood promotes equilibrium movement toward a greater liver distribution of the compound.

GP205 can efficiently inhibit replicons of different genotypes, except 3a, which is in parallel with simeprevir and most other Pls in the clinical phase [22, 34-37], with the genotype 3a ineffectiveness probably being because of a naturally occurring D168 mutation [38]. Moderate attenuation of the antivirus activity was observed in the genotype $1 \mathrm{~b}$ replicon assay in the presence of 20 and 40\% human serum, with $\sim 3$-fold and 4-fold shifts of the $\mathrm{EC}_{50}$ values, respectively, compared to that in $10 \%$ FBS medium. Administration of GP205 in combination with other DAAs will likely not be a problem, as additive to synergistic effects were observed in our combination study with sofosbuvir and daclatasvir. No cross-resistances were found for GP205 for either sofosbuvir or daclatasvir, as expected. The previously reported NS5A mutant Y93H, L31V [24], and NS5B mutant S282T [25] had no influence on the antiviral activity of GP205. Reduced activity (>100-fold) was observed for GP205 against the most frequently found resistance-associated substitution of Pls, D168 [39]. A minor activity shift occurred with the Q80K mutant, which had been reported to limit simeprevir's clinical use to genotype 1a patients [28]. Further drug resistance studies should be performed in clinical trials of GP205 in the future. Combination therapy using GP205 with other DAAs should be explored to overcome the resistance obstacle.

In summary, GP205 is a potent and selective HCV NS3/4A inhibitor. It can be used in combination with NS5B or NS5A inhibitors without cross-resistance and achieves additive to synergistic antiviral activity in vitro. Good plasma and liver exposure and a moderate plasma protein binding rate may be beneficial to its efficacy and safety in clinic. Our work supports further clinical trials with only GP205 and with GP205 in combination with drugs that are currently used against HCV infection.

\section{ACKNOWLEDGEMENTS}

This work was supported by the National Innovation Fund for technology-based firms (NO. 11C26213201274). The JFH-1 virus with an EGFP reporter gene (J399EM) was a gift from Xin-wen Chen (Wuhan Institute of Virology, Chinese Academy of Science).

\section{AUTHOR CONTRIBUTIONS}

$\mathrm{L}-\mathrm{qZ}$ and LC designed the study; P-bZ and JQ performed the research; BL contributed new reagents or analytic tools; L-qZ, LM, and LC analyzed the data; and P-bZ and JQ wrote the paper.

\section{ADDITIONAL INFORMATION}

The online version of this article (https://doi.org/10.1038/s41401-018-0046-2) contains supplementary material, which is available to authorized users.

Competing interests: The authors declare no competing interests.

\section{REFERENCES}

1. Lavanchy D. The global burden of hepatitis C. Liver Int. 2009;29(Suppl 1):74-81.

2. Pol S, Vallet-Pichard A, Corouge M, Mallet VO. Hepatitis C: epidemiology, diagnosis, natural history and therapy. Contrib Nephrol. 2012;176:1-9.

3. Gane EJ, Rouzier R, Hassanein T, Stedman CA, Mazur W, Kupcova V, et al. Ritonavir-boosted danoprevir-based regimens in treatment-naive and prior null responders with HCV genotype 1 or 4 and compensated cirrhosis. Hepatol Int. 2016;10:478-87. 
4. Smith RE. Hepatitis C virus therapies. Nat Rev Drug Discov. 2006;5:715-6.

5. Lawitz E, Sulkowski MS, Ghalib R, Rodriguez-Torres M, Younossi ZM, Corregidor A, et al. Simeprevir plus sofosbuvir, with or without ribavirin, to treat chronic infection with hepatitis $C$ virus genotype 1 in non-responders to pegylated interferon and ribavirin and treatment-naive patients: the COSMOS randomised study. Lancet. 2014;384:1756-65.

6. Manns M, Pol S, Jacobson IM, Marcellin P, Gordon SC, Peng CY, et al. All-oral daclatasvir plus asunaprevir for hepatitis $C$ virus genotype $1 \mathrm{~b}$ : a multinational, phase 3, multicohort study. Lancet. 2014;384:1597-605.

7. Zeuzem S, Ghalib R, Reddy KR, Pockros PJ, Ben Ari Z, Zhao Y, et al. GrazoprevirElbasvir combination therapy for treatment-naive cirrhotic and noncirrhotic patients with chronic hepatitis C Virus genotype 1, 4, or 6 infection: a randomized trial. Ann Intern Med. 2015;163:1-13.

8. Afdhal N, Zeuzem S, Kwo P, Chojkier M, Gitlin N, Puoti M, et al. Ledipasvir and sofosbuvir for untreated HCV genotype 1 infection. $N$ Engl J Med. 2014;370:1889-98.

9. Feld JJ, Jacobson IM, Hezode C, Asselah T, Ruane PJ, Gruener N, et al. Sofosbuvir and velpatasvir for HCV genotype 1, 2, 4, 5, and 6 infection. N Engl J Med. 2015;373:2599-607.

10. Feld JJ, Kowdley KV, Coakley E, Sigal S, Nelson DR, Crawford D, et al. Treatment of $\mathrm{HCV}$ with $\mathrm{ABT}-450 / \mathrm{r}-\mathrm{ombitasvir}$ and dasabuvir with ribavirin. N Engl J Med. 2014;370:1594-603.

11. Appel N, Schaller T, Penin F, Bartenschlager R. From structure to function: new insights into hepatitis C virus RNA replication. J Biol Chem. 2006;281:9833-6.

12. Freundt $E C$, Lenardo $M J$. Interfering with interferons: hepatitis $C$ virus counters innate immunity. Proc Natl Acad Sci USA. 2005;102:17539-40.

13. Jacobson IM, McHutchison JG, Dusheiko G, Di Bisceglie AM, Reddy KR, Bzowej $\mathrm{NH}$, et al. Telaprevir for previously untreated chronic hepatitis $\mathrm{C}$ virus infection. N Engl J Med. 2011;364:2405-16.

14. Poordad F, McCone J Jr, Bacon BR, Bruno S, Manns MP, Sulkowski MS, et al. Boceprevir for untreated chronic HCV genotype 1 infection. N Engl J Med. 2011;364:1195-206.

15. Njoroge FG, Chen KX, Shih NY, Piwinski JJ. Challenges in modern drug discovery: a case study of boceprevir, an HCV protease inhibitor for the treatment of hepatitis C virus infection. Acc Chem Res. 2008;41:50-9.

16. Lu J, Xiang Y, Tao W, Li Q, Wang N, Gao Y, et al. A novel strategy to develop a robust infectious hepatitis $C$ virus cell culture system directly from a clinical isolate. J Virol. 2014;88:1484-91.

17. Lin C, Lin K, Luong YP, Rao BG, Wei YY, Brennan DL, et al. In vitro resistance studies of hepatitis C virus serine protease inhibitors, VX-950 and BILN 2061: structural analysis indicates different resistance mechanisms. J Biol Chem. 2004:279:17508-14.

18. Middleton T, He Y, Pilot-Matias T, Tripathi R, Lim BH, Roth A, et al. A repliconbased shuttle vector system for assessing the phenotype of HCV NS5B polymerase genes isolated from patient populations. J Virol Methods. 2007;145:137-45.

19. Lin TI, Lenz O, Fanning G, Verbinnen T, Delouvroy F, Scholliers A, et al. In vitro activity and preclinical profile of TMC435350, a potent hepatitis $C$ virus protease inhibitor. Antimicrob Agents Chemother. 2009;53:1377-85.

20. Prichard MN, Shipman C Jr. A three-dimensional model to analyze drug-drug interactions. Antivir Res. 1990;14:181-205.

21. Yang N, Sun $Q, X u$ Z, Wang X, Zhao X, Cao Y, et al. LC-ESI-MS/MS analysis and pharmacokinetics of GP205, an innovative potent macrocyclic inhibitor of hepatitis $C$ virus NS3/4A protease in rats. Molecules. 2015;20:4319-36.

22. McPhee F, Sheaffer AK, Friborg J, Hernandez D, Falk P, Zhai G, et al. Preclinical profile and characterization of the hepatitis $C$ virus NS3 protease inhibitor asunaprevir (BMS-650032). Antimicrob Agents Chemother. 2012;56:5387-96.
23. Harper S, McCauley JA, Rudd MT, Ferrara M, DiFilippo M, Crescenzi B, et al. Discovery of MK-5172, a macrocyclic hepatitis C virus NS3/4a protease inhibitor. ACS Med Chem Lett. 2012;3:332-6.

24. Kumada H, Suzuki Y, Ikeda K, Toyota J, Karino Y, Chayama K, et al. Daclatasvir plus asunaprevir for chronic HCV genotype $1 \mathrm{~b}$ infection. Hepatology. 2014;59:2083-91.

25. Lam AM, Espiritu C, Bansal S, Micolochick Steuer HM, Niu C, Zennou V, et al. Genotype and subtype profiling of PSI-7977 as a nucleotide inhibitor of hepatitis $C$ virus. Antimicrob Agents Chemother. 2012;56:3359-68.

26. De Clercq E. Current race in the development of DAAs (direct-acting antivirals) against HCV. Biochem Pharmacol. 2014;89:441-52.

27. Alexopoulou A, Karayiannis P. Interferon-based combination treatment for chronic hepatitis $C$ in the era of direct acting antivirals. Ann Gastroenterol. 2015;28:55-65.

28. Jacobson IM, Dore GJ, Foster GR, Fried MW, Radu M, Rafalsky VV, et al. Simeprevir with pegylated interferon alfa $2 \mathrm{a}$ plus ribavirin in treatment-naive patients with chronic hepatitis C virus genotype 1 infection (QUEST-1): a phase 3, randomised, double-blind, placebo-controlled trial. Lancet. 2014;384:403-13.

29. Marcellin P, Cooper C, Balart L, Larrey D, Box T, Yoshida E, et al. Randomized controlled trial of danoprevir plus peginterferon alfa-2a and ribavirin in treatment-naive patients with hepatitis $C$ virus genotype 1 infection. Gastroenterology. 2013;145:790-800.e3.

30. Eley T, He B, Huang SP, Li W, Pasquinelli C, Rodrigues AD, et al. Pharmacokinetics of the NS3 protease inhibitor, asunaprevir (ASV, BMS-650032), in phase I studies in subjects with or without chronic hepatitis C. Clin Pharmacol Drug Dev. 2013;2:316-27.

31. Lok AS, Gardiner DF, Hezode C, Lawitz EJ, Bourliere M, Everson GT, et al. Randomized trial of daclatasvir and asunaprevir with or without PegIFN/RBV for hepatitis C virus genotype 1 null responders. J Hepatol. 2014;60:490-9.

32. FDA. Pharmacology Review(s) of OLYSIO. 2013. http://www.accessdata.fda.gov/ drugsatfda_docs/nda/2013/2051230rig1s000TOC.cfm.

33. FDA. Pharmacology review(s) of VIEKIRA PAK. 2014. http://www.accessdata.fda. gov/drugsatfda_docs/nda/2014/206619Orig1s000TOC.cfm.

34. Seiwert SD, Andrews SW, Jiang Y, Serebryany V, Tan H, Kossen K, et al. Preclinical characteristics of the hepatitis C virus NS3/4A protease inhibitor ITMN-191 (R7227). Antimicrob Agents Chemother. 2008;52:4432-41.

35. Pilot-Matias T, Tripathi R, Cohen D, Gaultier I, Dekhtyar T, Lu L, et al. In vitro and in vivo antiviral activity and resistance profile of the hepatitis C virus NS3/4A protease inhibitor ABT-450. Antimicrob Agents Chemother. 2015;59:988-97.

36. Summa V, Ludmerer SW, McCauley JA, Fandozzi C, Burlein C, Claudio G, et al. MK5172 , a selective inhibitor of hepatitis $C$ virus NS3/4a protease with broad activity across genotypes and resistant variants. Antimicrob Agents Chemother. 2012;56:4161-7.

37. Rajagopalan R, Pan L, Schaefer C, Nicholas J, Lim S, Misialek S, et al. Preclinical characterization and human microdose pharmacokinetics of ITMN-8187, a nonmacrocyclic inhibitor of the hepatitis C virus NS3 protease. Antimicrob Agents Chemother. 2017; 61:e01569-16.

38. Patino-Galindo JA, Salvatierra K, Gonzalez-Candelas F, Lopez-Labrador FX. Comprehensive screening for naturally occurring hepatitis $C$ virus resistance to directacting antivirals in the NS3, NS5A, and NS5B genes in worldwide isolates of viral genotypes 1 to 6. Antimicrob Agents Chemother. 2016;60:2402-16.

39. Romano KP, Ali A, Aydin C, Soumana D, Ozen A, Deveau LM, et al. The molecular basis of drug resistance against hepatitis $C$ virus NS3/4A protease inhibitors. PLoS Pathog. 2012;8:e1002832. 